\title{
On Analytic Theology
}

\author{
KEVIN TIMPE \\ Northwest Nazarene University \\ ktimpe@nnu.edu
}

\begin{abstract}
My primary aims in this paper are to give an overview of a recent movement which goes by the name of 'analytic theology', to locate that movement within the larger context of contemporary philosophy of religion, and to identify some of the weakness or objections that analytic theology will need to address moving forward. While I think that some of these objections have merit, I also think that the promise of analytic theology's contribution to theology more broadly is, in my view, sufficiently robust that we should continue to engage in it as a theological enterprise (even if one among many).
\end{abstract}

Keywords: analytic theology; philosophical theology; systematic theology; analytic philosophy.

\section{Introduction}

My primary aims in this paper are:

(i) to give an overview of a recent movement which goes by the name of 'analytic theology',

(ii) to locate that movement within the larger context of philosophy of religion, and

(iii) to identify some of the weakness or objections that analytic theology will need to address moving forward.

I begin with a rough comparison: analytic theology is to the 21st century what Augustine's use and adaptation of neo-Platonism and Aquinas' 
use and adaptation of Aristotle were to the fourth and thirteenth centuries, respectively. Since its inception, Christian theology has been engaging and appropriating (and, it should also be noted, critiquing) the philosophy of the day. As Richard Swinburne puts it, "the Christian theological tradition is very familiar indeed with the use of the best available secular criteria to clarify and justify religious claims" (Swinburne 2005, 40). And this kind of engagement with and use of analytic philosophy is what analytic theology is attempting to do, though in a particular way. Now I certainly don't mean to suggest that all Christian philosophical theology is 'analytic' in nature. Just as there is the purported (though hard to precisely pin down) difference between analytic and Continental philosophy, there are both analytic and Continental-inspired approaches to theology. And while recent years have seen some really interesting approaches to philosophy of religion that draw on what is usually seen as the Continental philosophical tradition, in this paper I'm going to limit the scope of my remarks to work which draws on analytic philosophy.

\section{Analytic Theology and Analytic Philosophy of Religion}

I've already suggested above that for much of its history, Christian theology has been engaging and incorporating the best philosophical approaches of the time into its theological task. The radical shift of medieval theology in the twelfth century with the reintroduction of Aristotle and his Arabic commentators to Christian Europe is perhaps the most striking example. However, the larger tendency dates back to many of the Patristics, and can also be seen throughout much of the theology of the modern period. More recently, especially during the early twentieth century, things shifted considerably for philosophical theology with the rise of logical positivism and positivist empiricism and, to a lesser extent, 'death of God' theology. For a few decades in the 20th century, philosophers of religion tried to defend the importance of their discipline despite the claim, which some of them endorsed, that talk about God wasn't even false but rather meaningless. Analytic philosophy of this sort wasn't particularly kind to philosophy 
of religion. In my experience, when many theologians think of analytic philosophy, this is the period that they think of. It's perhaps not surprising that they then find analytic philosophy to not be conducive to their theological task.

It's unfortunate, then, that many theologians are unaware that analytic philosophy of religion underwent a revival in the second half of the twentieth century as the wider ethos of analytic philosophy itself changed. Beginning in roughly the late 1960s, the influence of logical positivism and a certain kind of empiricism, which had dominated 20th-century Anglo-American philosophy and purportedly relegated philosophy of religion to meaninglessness in the process, started to wane. Traditional metaphysical claims again came into focus. During this 'metaphysical turn' of the 1970s, analytic philosophy of religion also entered a period of proliferation and continues to flourish to this day. During the 1980s and 1990s, philosophy of religion underwent a period of diversification, both in terms of topics and in terms of methodology. The sea-change has been so significant that Alan Torrance writes that theism's "explanatory power is now taken more seriously than at any time since the beginnings of modernity" (Torrance 2013, 30).

Commenting on the resurgence of philosophy of religion during this period, Eleonore Stump draws our attention to two major characteristics:

The first characteristic is a broad extension of subjects seen as appropriate for philosophical scrutiny. Not so long ago work in philosophy of religion was largely confined to discussions of the meaningfulness of religious language and examinations of arguments for the existence of God. In the work currently being done, however, philosophers have gotten their courage up and ventured into such areas as providence, creation, conservation, and God's responsibility for sin, areas where analytic precision is more difficult to attain but where the scope of the investigation is less constrained.

The second feature of the new work in philosophy of religion is a willingness to bridge boundaries with related disciplines, most notably with theology but also with biblical studies.... In leaving biblical studies entirely to historical scholars of the texts, contemporary philosophers were cutting themselves off 
from a fruitful source of data about individual religions and the contributions those data make to issues relevant to philosophers (Stump 1993, 1).

Not only have the changes in analytic philosophy opened up the scope of philosophy of religion, but recently Nicholas Wolterstorff has argued that the revival of philosophy of religion not only took place within but was made possible by analytic philosophy. He picks out three major developments that contributed to this revival:

(i) the death of logical empiricism, which had previously contributed to an anti-metaphysical bias;

(ii) the rejection of the view that "theistic belief, to be rationally and responsibly held, must be rationally grounded” (Wolterstorff 2009, 158); and

(iii) a renewed interest in meta-epistemology and alternate approaches to knowledge than classical foundationalism.

Within this analytic environment which at the least allows for and perhaps-if Wolterstorff is correct-actively encourages the flourishing of philosophy of religion, the diversity of philosophy of religion has continued, both in terms of the topics and in terms of the sources with which it starts. These two developments are interrelated. Analytic philosophy of religion is no longer limited to natural theology, which we can roughly understand as the attempt to establish truths about God or other theological matters on the basis of natural human reason, unaided by revelation. Natural theology typically focused on arguments for the existence of God, or how we should understand traditional divine attributes. But now energy is being spent on a richer philosophical project. Much contemporary philosophy of religion is what Scott MacDonald calls clarification:

The philosophical theologian engaged in clarification is not primarily concerned with the epistemic justification of [a particular view]. She is concerned instead with understanding, developing, systematizing, and explaining it. [The Christian philosopher] can legitimately undertake the investigation of not only the question of God's existence and attributes [issues associated with traditional natural theology] but also doctrines such as trinity, incarnation, and atone- 
ment- traditional paradigms of doctrines inaccessible to natural reason. When the philosopher takes up these kinds of issues with the aim of articulating and developing them, probing their internal coherence, joint consistency, and systematic connections, and exploring their relations to other theological and nontheological doctrines, she will be engaged in appropriately philosophical reflection on specifically Christian theological matters (MacDonald 2009, 24f).

Topics that have begun to be explored more fully in this manner include the Trinity, the Incarnation, the Atonement, heaven and hell; while otherssuch as the nature of Scripture and Revelation, the metaphysics of original sin-are only starting be the focus on inquiry. Of course, the clarification of many of these topics uses not only natural reason, but revelation, a particular understanding of religious tradition, or some other kind of appeal to authority. By expanding its sources of justification beyond mere reason, analytic theology can avoid some of the 'wing clipping' (Harris 2005, 101) that has plagued other approaches to philosophy of religion.

\section{The task of Analytic Theology}

A not-insignificant subset of what I've been calling analytic philosophy of religion aimed at clarification is what has recently been called analytic theology. Theologian William Abraham goes so far as to refer to "the emergence of analytic theology as a natural development with analytic philosophical theology" (Abraham 2013b, 3). And elsewhere he writes as follows:

Analytic theology did not begin with the publication of Analytic Theology [in 2009]. Richard Swinburne has been doing it for years; so have Basil Mitchell, John Lucas, and many others. All of my own work in theology is unintelligible if one does not know of my training in analytic philosophy. Yet this general point about the deeper history is insufficiently recognized. What we have now in play is a new and much more intentional phase of analytic theology (Abraham 2013a, 28).

I think it's best not to see analytic theology as distinct from analytic philosophy of religion (or from analytically influenced philosophical theology), 
but rather part of it. In his introduction to what is probably the best and most influential collection of relevant essays to date, Mike Rea describes analytic theology as follows:

Roughly (and I think that 'rough' is the best that we can do here), [the term 'analytic philosophy'] refers to an approach to philosophical problems that is characterized by a particular rhetorical style, some common ambitions, and evolving technical vocabulary, and a tendency to pursue some projects in dialogue with a certain evolving body of literature... As I see it, analytic theology is just the activity of approaching theological topics with the ambitions of an analytic philosopher and in a style that conforms to the prescriptions that are distinctive of analytic philosophical discourse (Rea 2009, 3 and 7).

In the inaugural issue of the recently launched Journal of Analytic Theology, ${ }^{1}$ Abraham describes the central ambitions of analytic philosophy (and thus of specifically analytic theology as well) as "first, to identify the scope and limits of our powers to obtain knowledge of the world; and, second, to provide such true explanatory theories as we can in areas of inquiry (metaphysics, morals, and the like) that fall outside the scope of the natural sciences" (Abraham 2013b, 6). Abraham's and Rea's descriptions, while not coextensive, I think jointly capture the approach to philosophicaland theological-issues that is characteristic of the analytic tradition (For worthwhile discussions of the differences between analytic and Continental approaches to philosophy, see Beaney 2013; Glock 2008; Levy 2003).

What is interesting from at least a sociological perspective is that while there are a number of theologians involved in analytic theology, judging by the work that has published thus far analytic theology seems to be spearheaded primarily by philosophers. Consider, for example, the afore mentioned Journal of Analytic Theology. While the senior editors are split between the disciplines of philosophy and theology, both executive editors, as well as approximately $2 / 3$ of the editorial board are housed in philosophy departments. And approximately the same disciplinary breakdown is

1 http://journalofanalytictheology.com/jat/index.php/jat. In addition to its content, another good feature of this journal is that it's open source. 
found in the contributors to Crisp and Rea's Analytic Theology collection. I suspect that one reason for this imbalance is a number of the objections to analytic theology, which I address in the subsequent section; many of them are more likely to be raised by theologians who might have methodological worries about analytic theology.

\section{Challenges and Criticisms}

It is probably clear from the material so far that I'm largely sympathetic with analytic theology, and I consider at least one of my books to be an instance of the approach (See Timpe 2013). However, as one should expect of any philosophical approach to, well, anything, analytic theology (and analytic philosophy of religion more broadly) is not without its critics. Here, I want to outline what seem to me to be some of the major issues facing analytic theology as it goes forward.

The first is a general statement about the general tenor of philosophy as a professional discipline, in at least the English-speaking world. Though things are considerably better than they were in the 1960s and 70s, the discipline of academic philosophy isn't always particularly fond of philosophy of religion. Basil Mitchell, for example, writes that "analytic philosophy of religion has always to some extent suffered from the taint of illegitimacy. Its practitioners have felt they needed to establish its credentials" (Mitchell $2005,21)$. As I already mentioned, things are considerably better than they have been in the past. But theism, or even an openness to theological issues, is significantly in the minority in the field. According to the recent PhilPapers survey, only $16 \%$ of philosophy faculty or PhDs accept or lean towards theism. ${ }^{2}$ This obviously puts pressure on those philosophers working in the area from their professional guild.

Not only are most philosophers skeptical of analytic theology, but many theologians are also skeptical of a specifically analytic approach to theology. As mentioned above, many theologians influenced more by Continental approaches seem to have been working with a limited understanding

2 http://philpapers.org/raw/survey.pdf 
of the nature of analytic philosophy in the past three (or more) decades. The turf and methodological battles are certainly not helped by the invocation, by two people involved in analytic theology, of Harry Frankfurt's work on 'bullshit' to characterize much recent theology (Abraham 2013b; Rauser 2009). As Billy Abraham puts it at one point, "analytic philosophers are fed up with the bullshit that shows up in theology and are determined to fix theology by doing it themselves" (Abraham 2013b, 3). Even if the philosophers in question are right to question the value (or orthodoxy or ...) of much of contemporary theology, the rhetorical strategy here certainly isn't likely to aid their cause.

In the introduction to their recent Faith and Philosophical Analysis: The Impact of Analytic Philosophy on the Philosophy of Religion, Harriet Harris and Christopher Insole write that "theologians are very resistant to engaging in the kind of reflection that analytical philosophers of religion employ... We should not assume that this is due to a sense of threat from philosophy. On the contrary, it is often because philosophers seem to theologians to take an inappropriate approach to the Bible, to religious phenomena[,] or to articles of faith" (Harris and Insole 2005, 17). Related here is the frequent charge that the God of analytic theology is the God of the philosophers, not the God of the Christian tradition-not the God of Abraham, Isaac, and Jacob, as it is sometimes put. According to some theologians, some of the philosophers involved in reflection on religion are more shaped by the history of and contemporary trends within their own discipline (and keep in mind here the frequent charge that analytic philosophy itself is too a-historical) than they are by the historical nature of the faith that they claim to be applying their philosophical tools to. Doing theology well requires engagement with sources, disciplines, and approaches that do not easily lend themselves to analytic analysis, and few philosophers have professional training in these areas. The philosopher seeking to address the Christian faith, Alan Torrance writes,

is obliged to engage with a book that is full of metaphor, rhetorical plays, and the semantic shifting of everyday concepts, not to mention the kind of counter- 
intuitive claims and hermeneutical dilemmas that would cause most analytic philosophers to turn to drink. This makes it tempting for theologians to allow the theism of natural theology to condition the distinctively historical character of knowledge of God as we find it presented in the philosophically counter-intuitive testimony of the Old and New Testaments (Torrance 2013, 31).

While this might be taken as a suggestion that analytic theology is misguided by the attempt to use tools other than those typically used in theology, that is not the point. "On the contrary," says Abraham,

we need the help of analytic theology to do justice to the God we meet in the worship of the Church. We can cut to the chase by noting that the God we have identified in our initial orientation is not some idol cooked up by philosophers, but precisely the God and Father of our Lord Jesus Christ, the triune God of Christian Creed and worship. The first task of a doctrine of God in analytic theology is to unpack as fully as possible what is involved in confessing that we believe in the triune God of the Church (Abraham 2009, 61f).

A related concern, and one that I think not only needs to be addressed but will be addressed as analytic theology matures a bit more, is that "analytic theology appears totally unrealistic when you look at what is needed to get the job done in theology" (Abraham 2013b, 4). The idea here is that doing theology well "involves initiation into several ancient and modern languages, into the historical study of scripture, into the history of the church and its teachings, and into normative assessment of the practices, ethics, and doctrines of the tradition" (Abraham 2013b, 4). Regarding the first part of Abrahams's worry, Marc Cortez, himself a theologian, suggests that if this objection cuts against analytic theology, it also cuts against most contemporary theology: "I shudder to think what would happen if many of these same standards were applied to theologians in general" (Cortez 2013, 22). But Cortez does worry about the "practical neglect of biblical texts in much of the theology that has been shaped by the analytic method" (Cortez 2013, 23).

Another worry with analytic theology that toughs on the above concerns is its scope. Even within 'theology proper' here, Abraham argues, the- 
ology is systematic in nature. But contemporary analytic philosophy isn't known for being historically sensitive and has few system-builders (David Lewis being the most obvious counterexample), tending instead to work by the division of intellectual division of labor. These two tendencies don't then lend analytic philosophers to do analytic theology with the historical sensitivity and overarching care that many theologians think is essential.

Yet another objection often raised is that the analytic style subverts the proper goals of theology, in its over-concern for clarity and precision. There's a worry here that "a certain kind of precisionist analysis can take us off track" (Abraham 2013b, 10) insofar as "the unguarded use of the analytic method [can] produce a hyper- intellectualism that values conceptual precision and winning arguments over spiritual formation and worship" (Cortez 2013, 24). Mike Rea expresses (but doesn't endorse) this objection as follows:

The prescriptions that characterize the analytic tradition reflect the wrong set of priorities. The problem with analytic philosophy is that it prioritizes clarity and precision at the expense of everything else, and it ignores the fact that sometimes, in order to attain wisdom and understanding, we have to rely substantively on metaphor and other literary tropes... The prescriptions that favor clarity and well-understood primitives and that proscribe substantive use of metaphor partly constrain our choice of topics. So, in other words, part of the concern is that philosophers will miss out on the pursuit of wisdom simply by ignoring rich and messy topics in favor of ones that admit of neat, precise, and literal discussion (Rea 2009, 18f).

In my view, this criticism is at least partially deserved, though like some of the other criticisms above, I suspect that this will change as analytic theology continues to mature.

A final criticism that I'll address here is that concern that theology is tied to the mission of the Church-encouraging people to love God and not just think true thoughts about Him-in a way that philosophy isn't. "If there's a weakness for analytic theology at this point, it is that analytically-minded theologians have often failed to put adequate time and effort 
into communicating the results of their research to the church. They often seem to feel that their work is done once they have constructed their technical arguments, leaving it to others to determine how best to integrate their insights into life and ministry" (Stump 2010, 24). And some of the concerns about analytic philosophy-e.g., its over-focus on left-brain skills, its over-valuing of "intricate, technically expert argument ... [which] has a tendency to focus more and more on less and less"-apply to analytic theology as well (Stump 2010, 24).

There are other objects as well that I don't have time to more than mention at present: that analytic theology, like analytic philosophy, is historically insensitive; that all metaphysical theorizing about God is a simulacrum or idolatrous; etc... It's not clear to me that any of these objections are fatal to the project of analytic theology. The totality of concerns that I've canvased does, however, raise some concerns that should be kept in mind and addressed as analytic theology goes forward if it is to live up to the expectations that many have for it. But I'm reasonably confident that those scholars (both philosophers and theologians) doing analytic theology can address these concerns moving forward. The promise of analytic theology and its potential contribution to theology more broadly are, in my view, sufficiently robust that we should continue to engage in it as a theological enterprise (even if one among many). ${ }^{3}$

\section{References}

Abraham, William J. 2009. "Systematic Theology as Analytic Theology.” In Analytic Theology: New Essays in the Philosophy of Theology, edited by Oliver D. Crisp and Michael C. Rea, 54-69. Oxford: Oxford University Press.

3 An earlier version of this paper was presented at Oxford University as part of a Science and Religion in Latin America project funded by the John Templeton Foundation. I am grateful to Ignacio Silve and Fr. Andrew Pincent for inviting me to take part in the conference. I would also like to thank Audra Jenson, Ben Arbour, Piotr Roszak, and two anonymous referees for comments and conversations about this paper. 
Abraham, William J. 2013. “Response to Marc Cortez.” Journal of Analytic Theology $1(1): 26-29$.

Abraham, William J. 2013. “Turning Philosophical Water into Theological Wine.” Journal of Analytic Theology 1 (1): 1-16.

Cortez, Marc. 2013. "As Much as Possible: Essentially Contested Concepts and Analytic Theology: a Response to William J. Abraham. Journal of Analytic Theology 1 (1): 17-24.

Glock, Hans-Johann. 2008. What is Analytic Philosophy? Cambridge University Press. Harris, Harriet A. 2005. "Does Analytical Philosophy Clip our Wings? Reformed Epistemology as a Test Case.” In Faith and Philosophical Analysis: The Impact of Analytical Philosophy on the Philosophy of Religion, edited by Harriet A. Harris and Christopher J. Insole, 100-118. Burlington, VT: Ashgate.

Harris, Harriet A. and Christopher J. Insole. 2005. "Verdicts on Analytic Philosophy of Religion.” In Faith and Philosophical Analysis: The Impact of Analytical Philosophy on the Philosophy of Religion, edited by Harriet A. Harris and Christopher J. Insole, 1-20. Burlington, VT: Ashgate.

Levy, Neil. 2003. "Analytic and Continental Philosophy: Explaining the Differences.” Metaphilosophy 34 (3): 284-304.

MacDonald, Scott. 2009. "What is Philosophical Theology?” In Arguing about Religion, edited by Kevin Timpe, 21-32. New York: Routledge.

Mitchell, Basil. 2005. "Staking a claim for metaphysics.” In Faith and Philosophical Analysis: The Impact of Analytical Philosophy on the Philosophy of Religion, edited by Harriet A. Harris and Christopher J. Insole, 21-32. Burlington, VT: Ashgate.

Rauser, Randal. 2009. “Theology as a Bull Session.” In Analytic Theology: New Essays in the Philosophy of Theology, edited by Oliver D. Crisp and Michael C. Rea, 70-685. Oxford: Oxford University Press.

Rea, Michael C. 2009. "Introduction. In Analytic Theology: New Essays in the Philosophy of Theology, edited by Oliver D. Crisp and Michael C. Rea, 1-30. Oxford: Oxford University Press.

Stump, Eleonore. 1993. “Introduction”. In Reasoned Faith: Essays in Philosophical Theology in Honor of Norman Kretzmann, edited by Eleonore Stump, 1-11. Ithaca, NY: Cornell University Press,.

Stump, Eleonore. 2010. Wandering in Darkness. Oxford University Press.

Stump, Eleonore. 2013. "Athens and Jerusalem: The relationship of philosophy and theology." Journal of Analytic Theology 1 (1): 45-59.

Swinburne, Richard. 2005. "The Value and Christian Roots of Analytical Philosophy of Religion.” In Faith and Philosophical Analysis: The Impact of Analytical Philosophy on the Philosophy of Religion, edited by Harriet A. Harris and Christopher J. Insole, 33-45. Burlington, VT: Ashgate. 
Timpe, Kevin. 2013. Free Will in Philosophical Theology. Bloomsbury.

Torrance, Alan J. 2013. "Analytic Theology and the Reconciled Mind: the Significance of History." Journal of Analytic Theology 1 (1): 3-44.

Wolterstorff, Nicholas. 2009. "How Philosophical Theology Became Possible within the Analytic Tradition in Philosophy." In Analytic Theology: New Essays in the Philosophy of Theology, edited by Oliver D. Crisp and Michael C. Rea, 155-169. Oxford: Oxford University Press. 
